\title{
Jeune syndrome
}

INSERM

\section{Source}

INSERM. (1999). Orphanet: an online rare disease and orphan drug data base. Jeune syndrome. ORPHA:474

Jeune syndrome, also called asphyxiating thoracic dystrophy, is a short-rib dysplasia characterized by a narrow thorax, short limbs and radiological skeletal abnormalities including "trident" aspect of the acetabula and metaphyseal changes. 